\title{
Evaluation of Antagonistic Activity of Milk Fermented with Kefir Grains of Different Origins
}

\author{
João Paulo Victorino Santos ${ }^{1 *}$, Tatiane Ferreira Araújo ${ }^{2}$, Célia Lúcia de Luces Fortes \\ Ferreira $^{2}$ and Simone Machado Goulart ${ }^{1}$ \\ ${ }^{I}$ Instituto Federal de Goiás; Itumbiara - GO - Brasil. ${ }^{2}$ Universidade Federal de Viçosa; Viçosa - MG - Brasil.
}

\begin{abstract}
In this study, the potential of kefir grains, obtained from three different towns/cities in the Southeast Region of Brazil to inhibit the growth of the five pathogenic microorganisms was evaluated. The samples showed the growth inhibition from 42.80-69.15 for Staphylococcus aureus ATCC 6538, 30.73-59.89 for Escherichia coli ATCC 11229, 44.99-73.05 for Salmonela typhi ATCC 6539, 41.45-54.18 for Listeria monocytogenes ATCC 15313 and 70.3886.80 for Bacillus cereus RIBO 1222-173-S4. These results indicated that the kefir grains evaluated had antagonistic activity toward the different pathogens tested. The ability to inhibit, although differently depending on the regional microbiota, indicated a potential for their use as a functional food.
\end{abstract}

Key words: kefir, antagonism, inhibitors, functional foods

\section{INTRODUCTION}

Kefir is a type of fermented milk and it is estimated to have originated before 2000 B.C. in the Caucasus Mountains in Russia. Its main characteristic is the presence of a diversified microbiota composed of lactobacillus, lactococcus, acetic acid bacteria and yeasts, besides other microorganisms, adhered to a matrix comprising polysaccharides, proteins and fats, which form the so-called kefir grains (Zhou 2009; Glibowski 2012). The presence of yeasts gives a particular character to the product due to the aroma, production of $\mathrm{B}$ complex vitamins and the activity of the product, even under refrigeration, with the production of ethanol and $\mathrm{CO}_{2}$ (Gorski 1994; Powell 2006). The product has been used for many years in Russia for the treatment of various types of illnesses. The functional properties attributed to kefir include retardation of cancerous tumors,
(Murofushi et al. 1983; Hosono et al. 1990; Hong et al. 2009), activation of the immunological system (Osada et al. 1994; Vinderola et al. 2005), possibility of consumption in cases of lactointolerance, combating of intestinal infections, and antagonistic activity toward pathogenic microorganisms (Hong et al. 2009), among others (Zubillaga 2001). Due to its microbiotic constituent, several different substances, which inhibit the growth of pathogenic microorganisms are produced, which are frequently associated with the illnesses of dietary origin (Magalhães et al. 2010; Tas et al. 2012). These inhibitory substances include hydrogen peroxide and bacteriocins (Helander et al. 1997).

Hydrogen peroxide is a metabolite produced by several species of lactic acid bacteria (LAB) and it contributes to the antagonistic effect on pathogenic microorganisms, and thus, aids in the preservation of food (Helander et al. 1997). The bactericidal

*Author for correspondence: joaopvsantos2@yahoo.com.br 
activity of is attributed hydrogen peroxide to its highly oxidant effect through the peroxidation of lipid membranes and the destruction of the basic molecular structure of the cellular proteins (Dahl et al. 1989).

Bacteriocins are protein compounds, which have lethal activity toward other bacteria. Normally, cellular bacteria, which produce bacteriocins are immune to their antagonistic action, giving the secretor bacteria a competitive advantage over other bacterial species in the same ecological environment (Naidu et al. 1999). Lactobacilli, widely present in kefir, can act in the degradation of proteins producing peptides with bactericidal action, which may constitute an important mechanism in the antagonistic activity toward pathogenic microorganisms (Yuksekgag et al. 2004).

The aim of this study was to evaluate the antagonistic effect of kefir originating from three towns/cities in the Southeast Region of Brazil on the following pathogenic microorganisms: Staphylococcus aureus ATCC 6538, Escherichia coli ATCC11229, Salmonella typhi ATCC 6539, Listeria monocytogenes ATCC 15313 and Bacillus cereus RIBO 1222-173-S4 and to check whether the origin of the kefir grains affected the antagonistic activity toward the pathogens evaluated.

\section{MATERIALS AND METHODS}

\section{Origin and Activation of Kefir Samples}

The kefir grains evaluated were obtained from three municipalities in the Southeast Region of Brazil: Viçosa/MG (K1), Caratinga/MG (K2) and São Paulo/SP (K3), and all were of artisanal origin. The methodology applied in this study was determined based on the experimental results obtained by Santos, (2008). For the activation, the kefir grains $(5 \%, w / v)$ were added to whole pasteurized milk at an ambient temperature of 20$25^{\circ} \mathrm{C}$ until coagulation (fermentation). The grains were then removed with the aid of a sieve, washed with distilled water and fermented again in a new substrate (whole pasteurized milk). The grains were activated through three consecutive fermentations and during the last activation, the fermented product was separated from the grains and matured under refrigeration at $8^{\circ} \mathrm{C}$ for $24 \mathrm{~h}$.

\section{Activation of Pathogens}

The pathogens, S. aureus E. coli, S. typhi, L. monocytogenes and $B$. cereus were activated in Brain Heart Infusion (BHI) broth (Difco, Detroit, USA) at $37^{\circ} \mathrm{C}$ for $24 \mathrm{~h}$ three times consecutively. Each active pathogen was diluted $(10 \%, \mathrm{v} / \mathrm{v})$ in phosphate buffer solution immediately before the test.

\section{Evaluation of pH}

The $\mathrm{pH}$ of the media used in the tests was determined immediately before the inoculation of the pathogens using a Digimed $\mathrm{pH}$ meter, model DMPH-2.

\section{Antagonism of Kefir}

In order to test the capacity of the kefir samples to inhibit the growth of the pathogenic microorganisms, the drink was sterilized by filtration method (Santos 2008). The kefir prepared with each of the samples K1, K2 and K3 was heated in a bain-marie at $50^{\circ} \mathrm{C}$ for $30 \mathrm{~min}$. The separated whey was filtered through cotton gauze twice and then centrifuged (CENTRÍFUGA

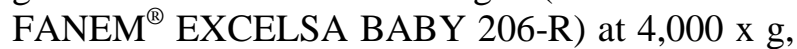
$15 \mathrm{~min}$. The supernatant was subjected to cold sterilization using a Millipore membrane (cellulose ester, $0.22 \mu \mathrm{m}$ pore size, $25 \mathrm{~mm}$ diameter). A volume of $2.5 \mathrm{~mL}$ of each whey sample was added to $2.5 \mathrm{~mL}$ of BHI (DIFCO) in transparent glass test tubes and inoculated with $0.05 \mathrm{~mL}$ of the diluted solution of each pathogen, separately and in duplicate (Table 1). The $\mathrm{pH}$ of the control tube was adjusted with a dilute hydrochloric acid $(\mathrm{HCl})$ solution $(1 \%, \mathrm{v} / \mathrm{v})$. The growth of the pathogenic microorganisms in the medium containing the sterile filtrate of each kefir sample was evaluated by spectrophotometry (Spectronic 20 D+ spectrophotometer) measuring the absorbance at $600 \mathrm{~nm}$, and compared with that of the control after incubation at $37^{\circ} \mathrm{C}$ after 0 and $8 \mathrm{~h}$.

\section{Statistical Analysis}

The test for the inhibition of the samples obtained from different kefir grains (K1, K2 and K3) in relation to the control was carried out with three repetitions, observing the absorbance readings at $600 \mathrm{~nm}$ by spectrophotometry. The averages of the results for each kefir sample in relation to each pathogen were compared statistically using the Newman-Keuls test at the 5\% significance level (Girard et al. 2009). 
Table 1 - Methodology for the evaluation of the antagonistic activity of kefir from different origins against pathogenic microorganisms.

\begin{tabular}{ll}
\hline Medium & Description \\
\hline Control & BHI broth $(2.5 \mathrm{~mL})$ added to distilled water $(2.5 \mathrm{~mL})$ \\
K1 & BHI broth $(2.5 \mathrm{~mL})$ added to whey of K1 $(2.5 \mathrm{~mL})$ \\
K2 & BHI broth $(2.5 \mathrm{~mL})$ added to whey of $\mathrm{K} 2(2.5 \mathrm{~mL})$ \\
K3 & BHI broth $(2.5 \mathrm{~mL})$ added to whey of K $3(2.5 \mathrm{~mL})$ \\
\hline
\end{tabular}

\section{RESULTS AND DISCUSSION}

The $\mathrm{pH}$ values of the media with the $\mathrm{K} 1, \mathrm{~K} 2$ and K3 samples were $6.05,6.04$ and 6.05 , respectively. In order to eliminate the possibility of interference in the results due to this factor, the control medium was adjusted to $\mathrm{pH} 6.05$.

Table 2 shows the percentage inhibition of each pathogen obtained for the samples K1, K2 and K3.

Table 2 - Percentage inhibition of the pathogens by kefir samples from different origins.

\begin{tabular}{lllll}
\hline Pathogens & K1 & K2 & K3 & Mean $\pm \mathbf{s}$ \\
\hline Listeria monocytogenes (ATCC 15313) & $41.45 \mathrm{a}$ & $48.61 \mathrm{a}$ & $54.18 \mathrm{a}$ & $48.08 \pm 6.38$ \\
Escherichia coli (ATCC 11229) & $59.89 \mathrm{a}$ & $59.87 \mathrm{a}$ & $30.73 \mathrm{a}$ & $50.16 \pm 16.38$ \\
Staphylococcus aureus (ATCC 6538) & $63.50 \mathrm{a}, \mathrm{b}$ & $69.15 \mathrm{a}$ & $42.80 \mathrm{~b}$ & $59.08 \pm 13.87$ \\
Salmonela typhi (ATCC 6539) & $65.35 \mathrm{a}$ & $73.05 \mathrm{a}$ & $44.99 \mathrm{a}$ & $61.13 \pm 14.50$ \\
Bacillus cereus (RIBO 1222-173-S4) & $72.88 \mathrm{a}$ & $86.80 \mathrm{~b}$ & $70.38 \mathrm{a}$ & $76.69 \pm 9.84$ \\
\hline
\end{tabular}

results in (\%) of inhibition related to the average of three repetitions, the averages for the samples K1, K2 and K3 followed by at least one letter the same did not differ when compared for each pathogen, at the 5\% significance level in the Newman-Keuls test.

All kefir samples showed an average reduction of at least $30 \%$ in the growth of the pathogens compared with the control. The maximum inhibitions occurred with sample K2 for the growth of B. cereus RIBO 1222-173-S4 (86.8\%) and S. typhi ATCC 6539 (73.05\%) and sample K1 for B. cereus RIBO 1222-173-S4 (72.88 \%). The pathogen, which presented the maximum inhibition was B. cereus RIBO 1222-173-S4 with an average reduction for the three kefir samples of $76.69 \%$ in relation to the control. The inhibition of $S$. aureus ATCC 6538 for the three samples varied from 42.80 to 69.15 . For the growth of $E$. coli ATCC 11229 the range of inhibition was 30.73 to 59.89 , and this pathogen showed the highest difference in the inhibition on comparing the three kefir samples. The inhibition for $S$. typhi ATCC 6539 was in the range of 44.99 to 73.05 , which for L. monocytogenes ATCC 15313 was 41.45 to 54.18 and for B. cereus RIBO 1222-173S4 was 70.38 to 86.80 .

According to the comparative analysis of the averages using the Newman-Keuls test at the 5\% significance level, the kefir samples showed variations in the inhibition of S. aureus ATCC 6538, with samples $\mathrm{K} 1$ and $\mathrm{K} 2$ being more efficient than K3, and B. Cereus RIBO 1222-173S4, with K2 showing higher inhibition than K1 and K3. These differences could be attributed to the different origins of the grains, with diversified microbiota and the possible presence of a variety of inhibitor agents. These results showed that the origin of the grains could influence their characteristics (Gorski 1994).

Several authors have studied the effect of kefir and its microbial flora on the inhibition of microbial activity in vitro, in relation to a large variety of Gram-positive and Gram-negative bacteria as well as some fungi. Several studies have demonstrated the antagonistic effect of kefir (Saloff-Coste 1996; Garrote et al. 2000; Güven and Goles 2003; Santos et al. 2003; Witthuhn et al. 2004), and in the latter two, the inhibition was observed in a fermented drink matured at $8^{\circ} \mathrm{C}$ for $24 \mathrm{~h}$, in relation to Gram (+) and Gram (-) bacteria without greater specifications. Yuksekgag et al. (2004) demonstrated that microorganisms isolated from the kefir grains inhibited the growth of $S$. aureus 
and Pseudomonas. These authors suggested that organic acids, hydrogen peroxide and other substances were responsible for the inhibition.

Pathogenic bacteria such as Shigella and Salmonella do not grow in the drinks fermented with kefir grains (Koroleva 1988). Lactobacillus acidophilus isolated from the kefir showed inhibitory activity toward various Gram $(+)$ and Gram (-) microorganisms (Gilliland and Speck 1977; Apella et al. 1992; Gupta et al. 1996). Of the different microorganisms isolated from kefir, Lactococcus and the acetic acid bacteria (AAB) were those which presented the maximum inhibitory effect on coliforms (Van 2001), and they also inhibited the growth of $S$. aureus, $B$. cereus, Clostridium tyrobutyricum and $L$. monocytogenes. Although the mechanism of pathogen inhibition by lactic acid bacteria (LAB) is not completely understood, it is known that these microorganisms inhibit the adherence, multiplication and pathogenic action of invasive microorganisms (Saavedra 1995). The antagonistic mechanisms of LAB may include the activity of organic acids, hydrogen peroxide (Shahani and Chandan 1979; Juven et al. 1992), diacetyl, bacteriocins and other compounds (Helander et al. 1997).

The $\mathrm{pH}$ conditions (6.05) used in the control treatment suggested that the presence of organic acids alone, produced by the metabolism of the bacteria present, was not sufficient to explain the results. This meant that the observed antagonism did not occur as a function of the low $\mathrm{pH}$ and, thus, other inhibitor substances might be present in the fermented drink based on the milk and kefir grains, since the thermal treatment employed to obtain the kefir filtrate $\left(50^{\circ} \mathrm{C}\right.$ for $\left.30 \mathrm{~min}\right)$ did not inactivate the substances such as the bacteriocins and hydrogen peroxide, which were resistant to temperatures of up to $63^{\circ} \mathrm{C}$ for $30 \mathrm{~min}$ (Piard and Desmazeaud 1991). The results orroborated the hypothesis that these chemical compounds present in the kefir grains were associated with antagonistic mechanisms against the pathogens.

\section{CONCLUSIONS}

Drinks fermented with kefir grains from different origins showed variations in the antagonistic activity toward the pathogens evaluated. The average percentage of inhibition varied between
48.08 and 76.69 for the microorganisms evaluated, and the maximum general inhibition was of sample K2 against B. cereus RIBO 1222-173-S4 $(86.80 \%)$. The ability to inhibit the kefir, although differently depending on the regional microbiota, indicated a potential for use as a functional food. In vivo studies and characterization of constituent microbiota are important for understanding the functional potential and can improve the quality of life when consumed regularly, especially for the children and elderly who are more sensitive to the imbalances in intestinal microbiota and subject to attacks by the opportunistic pathogens.

\section{ACKNOWLEDGEMENTS}

We thank the Department of Food Science from Universidade Federal de Viçosa.

\section{REFERENCES}

Apella MC, González SN, Macías MEN, Romero N, Oliver G. In vitro studies on the inhibition of the growth of Shigella sonnei by Lactobacillus casei and Lactobacillus acidophilus. J Appl Bacteriol. 1992; 73: 480-483.

Dahl TA, Midden WR, Hartman PE. Comparison of killing of Gram negative and Gram-positive bacteria by pure singlet oxygen. J Bact. 1989; 171: 21882194.

Garrote GL, Abraham AG, De Antoni GL. Inhibitory power of kefir: the ratio of organic acids. J Food Protect. 2000; 63: 364-369.

Gilliland SE, Speck ML. Antagonistic action of Lactobacillus acidophilus toward intestinal and foodborne pathogens in associative cultures. J Food Protect. 1977; 40: 820-823.

Girardi LH, Filho AC, Storck L. Erro tipo I e poder de cinco testes de comparação múltipla de médias. Rev Bras Biom. 2009; 27(1): 23-36.

Glibowski P, Kowalska A. Rheological, texture and sensory properties of kefir with high performance and native inulin. J Food Eng. 2012; 111(2): 299-304.

Gorski D. Kefir: 21 st century yogurt? Dairy Foods; 1994. p. 95-149.

Gupta PK, Mital BK, Garg SK. Inhibitory activity of Lactobacillus acidophilus against different pathogens in milk. J Food Sci Technol. 1996; 33: 147-149.

Güven A, Gülmez M. The effect of kefir on the activities of GSH-Px, GST, CAT, GSH and LPO levels in carbon tetrachloride-induced mice tissues. $J$ Vet Med. 2003; 50: 412-416. 
Helander IM, von Wright A, Mattila-Sandholm TM. Potential of lactic acid bacteria and novel antimicrobials against Gram-negative bacteria. Trends Food Sci Technol. 1997; 8: 146-150.

Hong WS, Chen HC, Chen YP, Chen MJ. Effects of kefir supernatant and lactic acid bacteria isolated from kefir grain on cytokine production by macrophage. Int Dairy J. 2009; 19(4): 244-251.

Hosono A, Tanabe T, Otani H. Binding properties of lactic acid bacteria isolated from kefir milk with mutagenic amino acid pyrolyzates. Milchwissenschaft. 1990; 45: 647651.

Juven BJ, Schved F, Linder P. Antagonistic compounds produced by a chicken intestinal strain of Lactobacillus acidophilus. J of Food Protect. 1992; 55: 157-161.

Koroleva NS. Technology of kefir and kumys. Bull IntDairy Fed. 1988; 277: 96-100.

Magalhães KT, Pereira GVM, Dias DR, Schwan RF. Microbial communities and chemical changes during fermentation of sugary Brazilian kefir. World $J$ Microbiol Biotechnol. 2010; 26(2): 1241-1250.

Murofushi M, Shiomi M, Aibara K. Effect of orally administered polysaccharide from kefir grain on delayed-type hypersensivity and tumor growth in mice. J Med Sci Biol. 1983; 36: 49-53.

Naidu AS, Bidlack WR, Clemens RA. Probiotic spectra of lactic acid bacteria (LAB). Crit Rev Food Sci. 1999; 38: 26-34.

Osada K, Nagira K, Teruya K, Tachibana H, Shirahata $\mathrm{S}$, Murakami H. Enhancement of interferon- $\beta$ production with sphingomyelin from fermented milk. Biotherapy. 1994; 7(2): 115-123.

Piard JC, Desmazeaud M. Inhibiting factors produced by lactic acid bacteria. II. Bacteriocins and other antibacterial substances. Lait. 1991; 71(5): 525-541.

Powell JE. Bacteriocins and bacteriocin producers present in kefir and kefir grains. [MSc Thesis]. Stellenbosch South Africa: Stellenbosch University; 2006.

Saavedra JM. Microbes to fight microbes: a not so novel approach to controlling diarrheal diseases. $J$ Pediatr Gastroenterol Nutr.1995; 21: 125-129.

Saloff-Coste CJ. Kefir: Nutritional and health benefits of yoghurt and fermented milks. Danone World Newsletter. 1996; 11: 1-7.
Santos A, san Mauro M, Sanchez A, Torres JM, Marquina D. The antimicrobial properties of different strains of Lactobacillus spp. Isolated from kefir. Syst Appl Microbiol. 2003; 26: 434-437.

Santos JPV. Avaliação da microbiota de grãos de kefir e atividade inibidora da bebida sobre algumas bactérias patogênicas. [MSc Thesis]. Viçosa Brazil: Universidade Federal de Viçosa, 2008.

Shahani KM, Chandan RC. Nutritional and healthful aspects of cultured and culture-containing dairy foods. J Dairy Sci. 1979; 62: 1685-1694.

Tas TK, Ekinci FY, Guzel-seydim ZB. Identification of microbial flora in kefir grains produced in Turkey using PCR. Int J Dairy Technol. 2012; 65 (1):126131.

Van WJ. The inhibitory activity and sensory properties of kefir, targeting the low-income African consumer market. [MSc Thesis] Stellenbosch South Africa: University of Stellenbosch, 2001.

Vinderola CG, Duarte J, Thangavel D, Perdigón G, Farnworth E, Matar C. Immunomodulating capacity of kefir. J Dairy Res. 2005; 72: 195-202.

Witthuhn RC, Schoeman T, Britz TJ. Isolation and characterization of the microbial population of different South African kefir grains. Int J Dairy Technol. 2004; 57: 33-37.

Yuksekgag ZN, Beyatli Y, Aslim B. Determination of some characteristics coccoid forms of lactic acid bacteria isolated from Turkish kefirs with natural probiotic. Lebensm Wiss U Technol. 2004; 37: 663667.

Zhou J, Liu X, Jiang H, Dong M. Analysis of the microflora in Tibetan kefir grains using denaturing gradient gel electrophoresis. J Food Microbiol. 2009;26(8) 770-775

Zubillaga M. Effect of probiotics and functional foods and their use in different diseases. Nutr Res. 2001; 21: 569-579. 